\title{
Toplumsal Cinsiyetin Şirketlere Yansımasında Ortaya Çıkan Ayrımcılık Kavramlarının Ardılları Üzerine Bir Model Önerisi
}

\author{
Sebahattin YILDIZ*
}

Toplumsal Cinsiyetin Şirketlere Yansımasında Ortaya Çıkan Ayrımcılık Kavramlarının Ardılları Üzerine Bir Model Önerisi

\section{Özet}

Şirketlerde kadın ve erkeğin biyolojik ve beşeri sermaye farklılıklarından kaynaklanmayan toplumsal cinsiyete dayalı ayrımcılık söz konusu olabilmektedir. Derleme niteliğinde hazırlanan bu çaIışmada sosyolojik ve ekonomik kuramlar bağlamında incelenen bu ayrımcılığın şirketlere yansımasında ortaya çıkan kavramları belirlemek ve bu kavramların işle ilgili çıktılara etkilerini incelemek amaçlanmıştır. Kapsamlı bir yazın araştırması neticesinde cam uçurum, cam asansör, cam yürüyen merdiven, cam duvar, cam labirent, göstermecilik ve çifte açmaz gibi kavramların toplumsal cinsiyet bağlamında kadınlarla ilgili şirketlere yansıyan ayrımcılık kavramları olduğu ortaya çıkmıştır. Ayrıca bu kavramların kadınlar tarafından algılanmasının ardılları olan işle ilgili çıktılar üzerindeki olumsuz etkisine dair bir model geliştirilmiştir.

Anahtar Kelimeler: Toplumsal Cinsiyet, Cinsiyet Ayrımallı̆̆ı İ̧sle ilgili Çıktılar, Cam Uçurum, Göstermecilik
A Model Proposal on Consequences of Discrimination Concepts Emerging on The Reflection of Gender on Corporations

Abstract

In corporations, there may be a gender-based discrimination that is not caused by biological and human capital differences of woman and man. The purpose of this study, prepared as a review, is to determine the concepts arising in the reflection of this discrimination, examined within the context of sociological and economic theories, on corporations and examine the effects of these concepts on business-related outputs. As a result of a comprehensive literature review, it has been revealed that concepts like glass cliff, glass elevator, glass escalator, glass wall, glass labyrinth, tokenism, and double bind are discrimination concepts reflected on corporations concerning women within the context of gender. Furthermore, a model has been developed regarding the negative effect of the perception of these concepts by women on business-related outputs, which are their consequences.

Key Words: Gender, Gender Discrimination, Job-Related Outcomes, Glass Cliff, Tokenism

\section{Giriş}

Toplumsal cinsiyet eşitsizliğini anlatan yaklaşımlar genellikle "toplumsal cinsiyetin kuramsal analizi" ve "feminist yaklaşım" şeklinde ikiye ayrılmaktadır (Başak, 2013: 222). Biyolojik cinsiyet (sex) kadın ve erkeğin fiziksel ve biyolojik farklııklarını ifade ederken, toplumsal cinsiyet (gender), toplum bağlamında kullanılan daha geniş bir kavramdır ve kadın ve erkek olarak kişinin sosyal rolüyle ilgili olan duygular, tutumlar, davranışlar ve ilgilerini belirtir (Lamsa, Jyrkinen ve Heikkien, 2012: 5-6).

\footnotetext{
* Sebahattin YILDIZ, Doç.Dr., Kafkas Üniversitesi, İşletme Bölümü, syildiz@kafkas.edu.tr
} 
Sebahattin YILDIZ

"Toplumsal cinsiyet, kadın ve erkeğin toplumsal rol ve sorumluluklarının biyolojik farklılıklarından kaynaklanmadığını, bunu sosyalleşme süreci içinde kültürel olarak öğrendiklerini ve toplum tarafından onlara atfedildiklerini anlatmaktadır" (Demir, 2011: 98). Feminist hareketler de toplumsal cinsiyet eşitsizliklerini açıklamayı ve üstesinden gelmeyi amaçlamaktadır. Feminist kuramlar, toplumsal cinsiyet eşitsizliklerini toplumun derinliklerine kök salmış cinsiyetçilik, ataerkillik ve kapitalizm gibi toplumsal süreçler vasıtasıyla açıklamaya çalışmışlardır (Giddens, 2012: 516-517).

Bu itibarla, ataerkil toplum yapısından ve kültürden kaynaklanan şirketlerdeki cinsiyet ayrımcılı̆̆ıla ilgili kavramları tanıtmak araştırmanın birinci amacıdır. Araştırmanın ikinci amacı ise Blau'nun (1964) Sosyal Mübadele Teorisi çerçevesinde bu kavramların algılanmasının işle ilgili çıktılar üzerindeki etkilerini içeren bir model önerisinde bulunmaktır. Yabancı yazında yer almasına rağmen, bu çalışmada bahsedilen ve tartışılan kavramlarla ilgili Türkiye'de çok az çalışma olması (Yıldız, Alhas, Sakal ve Yıldız, 2016) bu araştırmanın temel katkısı olabilecektir.

\section{Kuramsal Çerçeve}

Cinsiyet ayrımcılığı konusunun şirketlere yansımasında ortaya farklı kavramlar çıkmaktadır fakat Türkçe yazında sadece cam tavan kavramı incelenmiştir. Bu kavramlar kadınların üst düzey yönetim pozisyonları için uygun görülmemelerini ifade etmekte kullanılan ve kariyer engeli sayılabilecek birbirinden farklı kavramlardır. Cam yürüyen merdiven (glass escalator), cam duvar (glass wall), cam asansör (glass elevator), göstermecilik/göstermelik ödün verme (tokenism), cam labirent (glass labryrinth), çifte açmaz (double bind) ve cam uçurum (glass cliff) gibi kavramların kuramsal açıklaması toplumsal cinsiyet kuramları, feminist kuramlar ve diğer sosyolojik ve ekonomik kuramlar çerçevesinde olabilmektedir. Bu itibarla çalışmanın bu kuramsal çerçeve kısmında, şirketlerdeki cinsiyet ayrımcılığı kavramlarının yani kadınların üst kademe yönetici olamamalarını açıklamaya çalışan kavramların kuramsal temelleri anlatılmıştır.

\subsection{Toplumsal Cinsiyet Kuramları}

Toplumsal cinsiyet farklılıklarına ilişkin açıklamalar üç ana yaklaşım içinde aşama kaydetmiştir. Bunlar: (1) doğacı/biyolojik/fıtri/özgü yaklaşım (cinsiyetle ilgili farklılıkları ortaya çıkaran yaradılış/biyolojik özelliklere ve kadın-erkek olmanın temelinde doğa olduğuna vurgu yapar), (2) toplumsal cinsiyetin toplumsallaşması yaklaşımı (kadın ve erkek olmanın temelinde toplumsallaşma olduğuna, cinsiyet rollerinin aile, medya, arkadaş grupları gibi aracılar yoluyla öğrenilerek toplumsallaşma gerçekleştiğine ve toplumsal cinsiyet farklılıklarının biyolojik olarak değil kültürel olarak üretildiğine vurgu yapar), (3) cinsiyetin ve toplumsal cinsiyetin toplumsal inşası yaklaşımı (kadın ve erkekler arasındaki farlılıkları belirleyenin ne biyoloji ne de toplumsallaşma olduğuna, hem cinsiyet hem de toplumsal cinsiyetin bireylerin öznel tercihleri sonucunda toplumsal olarak kurulduğuna vurgu yapar ve cinsiyetin ve toplumsal cinsiyetin temelinde bireyi gösterir) şeklindedir (Başak, 2013: 213-220). 
Farklı bir sınıflandırmaya göre toplumsal cinsiyet kuramları (1) biyolojik kuram (biyolojik özelliklere dayalı rol farklılığından bahseder), (2) sosyal rol kuramı (toplumda sosyalleşmeye dayalı üstlenilen rollerin farkılığını belirtir), (3) etkileşimsel model (kişisel seçim, diğer kişilerin davranışları ve bağlama vurgu yapar), (4) sosyal öğrenme kuramı (cinsiyetine uygun rol modelini öğrendiğini söyler), (5) bilişsel gelişim kuramı (bilişsel bilgi işleme süreci yoluyla cinsel kimlik geliştirilir), (6) sosyal baskınlık kuramı (statüsü yüksek olan grubun baskınlığı da yüksek olur) şeklindedir (Güldü ve Ersoy Kart, 2009: 101-108).

Yazara göre, şirketlerde cinsiyet ayrımcılığının ortaya çıkardığı ve bir kariyer engeli sayılabilecek yukarıda bahsedilen kavramların kuramsal temelleri biyolojik farklılıklardan ziyade toplumsallaşma süreci veya kişisel tercih ile açıklanabilir. Bu itibarla, kadınlar şirketlerde üst düzey yönetim pozisyonları için uygun görülmediklerini ya sosyalleşme sürecinde öğrenebilirler ya da bu pozisyonları aile öncelikleri dolayısıyla tercih etmeyebilirler. Cinsiyet ayrımcılığı kavramlarını açıklamada aşağıda belirtilen feminist kuramlar da katkı sunmaktadır.

\subsection{Feminist Kuramlar}

"Feminist kuramlar kadınların ataerkil toplumsal düzen yapısı içinde değersizleştiklerini varsaymakta ve bunun nedenini sorgulamaktadırlar" (Aktaş, 2013: 62). Feminist yaklaşımlar liberal, radikal ve marksist/sosyalist feminizm olarak sınıflandırılabilir. (1) Liberal feminizm, kadın hakları için mücadele eden bir yaklaşımdır ve kadınların erkekler gibi eşit hak ve özgürlüklere sahip olmasını talep etmektedir. Kadın ve erkekler arasındaki güç ilişkilerini sorgulamaz ancak kadınların kadın olmasından kaynaklı ezildiklerini kabul eder. (2) Radikal feminizm, kadınların ezilmişliğinin nedenlerini ataerkil yapı ve ilişkilere dayandırmaktadır. Kadınlara uygulanan baskı, cinsellik, aile içi şiddet, ev içi işbölümünü eleştirilmektedir. (3) Marksist/sosyalist feminizm eşit işe eşit ücret verilmesi, ev işlerinin ücretlendirilmesini istemektedir (Çakır, 2010: 437-460; Demir, 2011: 113).

Feminist araştırmalarda kamusal alan veya özel alan, ev içi iş veya ev dışı iş, doğal veya kültürel ayrımları eleştirilmektedir (Ersoy Çak, 2010: 103). Toplumsal cinsiyet temelli ayrışma nedeniyle genel olarak kadın işleri düşük statülü, düşük ücretli, geçici, güvencesiz olan niteliksiz işlerden oluşurken, erkek işleri yetki ve sorumluluk gerektiren, yüksek ücretli, güvenceli olan nitelikli işlerden oluşmaktadır. Kadınlar yönetimle ilgili, bilgi ve teknoloji tabanlı işlerden ziyade daha çok bakım hizmeti, halk sağlığı ve rutin işlere yönlendirilmektedirler. Ayrıca aynı beşeri sermaye donanımına sahip olan kadınların aynı meslekteki erkeklere göre üst kademe yönetim pozisyonlarına ulaşamaması ve terfi ayrımcılığına maruz kaldığı gözlenmektedir (Parlaktuna, 2010: 1222).

Birinci dalga feminist kuram, modern sosyoloji kuramlarından birisidir ve 18. yüzyıl Aydınlanma döneminde eşitlik, bireysel özgürlükler ve hak arayışı şeklinde yazında yer almıştır. İkinci dalga feminizm ise 1960 'ı yıllarda ortaya çıkmıştır ve biyolojik cinsiyet (sex) ile toplumsal ve kültürel olarak inşa edilen toplumsal cinsiyet (gender) arasında bir ayrımı vurgulamaktadır (Yıldız vd., 2016: 1125). Biyolojik özelliklerine vurgu yaparak kadın ve erkek arasındaki eşitsizliğin açıklanması yeterli olmamakta ve cinsiyet eşitsizliği toplumsal ve kültürel olarak üretilen bir güç ilişkisi olmaktadır. Bu toplumsal ve 
Sebahattin YILDIZ

kültürel süreçler kadın ve erkeklere birbirinden farklı rol ve sorumluluklar yükleyen toplumsal cinsiyete dayalı bir işbölümü yaratmaktadır. Toplumsal yaşam kadın ve erkeklerin rol ve sorumluluklarına göre özel alan (ev merkezli) ve kamusal alan (ev dışı) gibi iki farklı alanda tanımlanmaktadır. Cinsiyete dayalı işbölümü, erkek egemenliği ve kadın emeği gibi özel alanla ilgili konular feministlerce sorgulanmaya başlamıştır. Feminist kuramlar kadınların ezilmişliği, erkeklerin kadınlar üzerinde kurduğu egemenlik, baskı ve kontrol sistemini ifade eden ataerkillik gibi konuları analiz etmektedir (Koçak Turhanoğlu, 2012: 21-22).

Feminist iktisat teorisine göre, patriarkal (erkek egemen) sistem ve kadının toplum ve aile içindeki ikincil pozisyonu, kadının işgücü piyasasındaki dezavantajlı durumuna neden olmaktadır. Hem patriarkal sistem hem de sorumlulukların cinsiyete göre ayrıştırılması işgücü piyasasındaki ayrımcılığın nedenleri olarak sayılabilir. Kadınların erkeklere nazaran daha az okutulması, iş hayatında erkeklere kıyasla daha az tecrübe sahibi olmaları, bilim ve teknik alanlarda -doğurganlık özellikleri nedeniyle- uzmanlaşamamaları gibi durumlar işbölümü çerçevesinde incelenebilir. Feminist iktisat teorisi cinsiyete dayalı mesleki katmanlaşmayı (tabakalaşmayı) yatay ve dikey olarak iki boyutta ele almaktadır. Yatay katmanlaşma, mesleklerin kadın işleri ve erkek işleri olarak ayrılması iken dikey katmanlaşma aynı meslekteki kadın ve erkeklerin farklı iş pozisyonlarında yer almasını ifade etmektedir (Parlaktuna, 2010: 1220).

Yazara göre, kadın ve erkek arasındaki eşitsizlik birinci dalga feminist kuramlarla açıklanamayabilir. Çünkü kadınların yasal haklara sahip olmalarına rağmen ikinci dalga feminist kuramların belirttiği gibi ataerkil toplum yapısı nedeniyle ve önyargılar sonucu eşitsizlik hala devam etmektedir. Bu itibarla kadınlar şirketlerde üst düzey yönetim pozisyonlarına cinsiyete dayalı bir işbölümü, özel alana layık görülmeleri ve kültürel olarak oluşturulan önyargılar nedeniyle uygun görülmeyebilirler. Cinsiyet ayrımcılığı kavramlarını açıklamada aşağıda belirtilen diğer kuramlar da söz konusudur.

\subsection{Diğer Kuramlar}

Cinsiyet ayrımcılığının ortaya çıkardığı kavramları açıklamaya yönelik diğer kuramlar şunlardır: (1) ikili rol kuramı (kadının iş ve aile ikilemine vurgu yapar), (2) insana yatırım/beşeri sermaye kuramı (erkek egemen işyerleri devamlı statüde olan ve işe yönelik beklentileri fazla olan erkeğe yatırım yapar), (3) istatistiksel ayrımcılık kuramı (işe alma aşamasında işten ayıııma oranı, aidiyet vb önceki istatistiki verilere bakılarak karar verilir), (4) cinsiyet rol uygunluğu kuramı (kadın ve erkekler toplumdan beklenen rollere uygun davranırlar) ve (5) bölümlenmiş işgücü piyasaları yaklaşımıdır (birincil ve ikincil piyasalara atıf yapar. Kadınlar genellikle ücretlerin düşük ve yükselme olanağını az olduğu ikincil piyasada yer alır) (Erbay ve Tuncay, 2006: 29; Yoğun Erçen, 2008: 15).

Beşeri ve sosyal sermaye kuramları da şirketlerde cinsiyet ayrımcılığı kavramlarını açıklayabilir. Beşeri sermaye kuramı insana ait bilgi, beceri ve kazanılmış diğer yeteneklerinin değerini ifade eder ve bunlara sahip bireylerin daha başarılı olabileceğini savunur. Sosyal sermaye kuramı ise başarıyı bireylerin yeteneklerinden ziyade sosyal ağlara sahip olmasına bağlamaktadır (Alican, 2007: 22-23). 
Yazara göre, bu kuramlar ışığında kadınların üst kademe yönetim pozisyonlarında yer alamamaları şu şekilde açıklanabilir. İ̧verenlerin erkeklere daha fazla yatıım yapmalarından dolayı erkeklerin beşeri sermayeleri kadınlara göre daha fazla olabilmektedir. Ayrıca aynı beşeri sermayeye düzeyinde olsalar bile kadınların grup dinamiğine ve sosyal ağlara daha az girebilmelerinden dolayı üst kademe yöneticilik pozisyonlarına ulaşmak kadınlar için zor olabilmektedir.

Cinsiyet ayrımcılı̆ıı ile ilgili ortaya çıkan ve kariyer engeli sayılabilecek kavramların kuramsal temelleri yukarıda anlatılmıştır. Bundan sonraki başıkta ise bu kavramların neler olduğuna değinilmiş ve bu kavramların kadınlarca algılanmasının ardılları için bir model önerisi tartışılmıştır.

\section{Toplumsal Cinsiyetin Şirketlere Yansımasında Ortaya Çıkan Cinsiyet Ayrımcılığı Kavramları Ve Bir Model Önerisi}

Kapsamlı bir yazın araştırması neticesinde şirketlerde kadınların yaşadığı cinsiyet ayrımcılığını vurgulayan aşağıda belirtilen kavramlara ulaşılmıştır ve bu kavramlar tanıtılarak araştırmanın birinci amacı gerçekleştirilmiştir. Cam uçurum, cam asansör, cam yürüyen merdiven, cam duvar, cam labirent, göstermecilik ve çifte açmaz kavramları, kadınların üst kademe yönetici olamamalarındaki engelleri açıklamakta kullanımaktadır. Bu cinsiyet ayrımcılı̆̆ı kavramlarının kuramsal temelleri, kadınlara uygulanan cinsiyet ayrımcılığında "ikinci dalga" feminist kuramlar bağlamında, ataerkil zihniyete ve kültüre bağlanarak ele alınabilir.

Araştırmanın ikinci amacı ise, ulaşılan bu kavramların işle ilgili çıktılara etkilerini ortaya koyacak bir model önermektir. Bu kavramların şirketlerdeki kadınlarca algılanması, kadınların tutumlarını olumsuz yönde etkileyebilecektir. Dolayısıyla Blau'nun (1964) sosyal mübadele teorisine yoluyla bir model önerilmiştir. Blau'ya göre algı-tutum-davranış arasında iktisadi temele dayanmayan bir mübadele ilişkisi vardır. Dolayısıyla tutum ve davranışlar çeşitli algıların sonucudur. Pozitif algılar pozitif tutumlara neden olurken negatif algılar ise negatif tutumlara neden olabilecektir. Teoriye göre cinsiyet ayrımcılığıyla ilgili yazında ulaşılan kavramlarla ilgili algılar (örneğin cam uçurum) kadınların işle ilgili tutumlarını (örneğin iş tatmini) etkileyebilecektir.

Modelin kuramsal zeminini (Blau, 1964) ifade ettikten sonra yazında yapılan ampirik çalışmalar da incelenmiştir. Buna göre şirketlerde algılanan cinsiyet ayrımcılığının, işle ilgili çıktılardan iş gerginliğini (Sanchez ve Brock, 1996), işten ayrılma niyetini (Onay, 2009) ve yaşam stresini (Shaffer vd., 2000) pozitif yönde; örgütsel bağlılı̆ı ve iş tatminini, (Sanchez ve Brock, 1996; Shaffer vd., 2000; Ensher vd., 2001; Onay, 2009), örgütsel vatandaşlık davranışını (Ensher vd., 2001) ve işe bağılı̆ı̆ı (Peng vd., 2009) negatif yönde etkilediği bulunmuştur. Fakat yazında incelenen çalışmalarda bu araştırmanın birinci amacında ulaşılan kavramlar kullanılmamış, algılanan cinsiyet ayrımcılığı ücret, terfi, imkânlar vb ifadelerle genel ölçülmüştür. Dolayısıyla bu çalışma yazındakilerden farklıdır ve bir boşluğu doldurmaktadır.

Bu kuramsal ve ampirik çerçeve ışı̆̆ında, çalışanlar işyerlerinde ayrımcılı̆̆a maruz kaldıklarını algıladıklarında kendilerini işe veremeyecek ve işle ilgili olumsuz çıktılarında (örneğin işten ayrılma niyetinde, iş stresi vb) bir artış gözlenebilecekken, bu şekilde bir ayrımcılık hissetmeyenlerin ise işle 
Sebahattin YILDIZ

ilgili olumlu çıktılarında (örneğin örgütsel bağlıık, iş tatmini ve örgütsel vatandaşlık davranışı) bir iyileşme gözlenebilecektir.

Bu itibarla kadınlar ve iş dünyası için yaygın bir problem olan algılanan cinsiyet ayrımcılı̆̆ının ortaya çıkardığı ve araştırmanın birinci amacında ulaşılan cam asansör, cam yürüyen merdiven, göstermecilik/göstermelik ödün verme, çifte açmaz, cam duvar, cam labirent ve cam uçurum kavramları aşağıda açıklanmış ve bu kavramların işle ilgili çıktılar üzerindeki olumsuz etkileri için bir model önerilerek araştırmanın ikinci amacına ulaşılmıştır.

\subsection{Cam Asansör ve Cam Yürüyen Merdiven}

Bazı grupların örgütsel hiyerarşide yukarıya doğru hareketini (dikey katmanlaşma) engelleyen cam tavanın aksine, cam asansör ve cam yürüyen merdiven, örgütsel hiyerarşide bazı azınlık grupların daha hızlı bir şekilde yükselişini belirtmede kullanılan metaforlar yani mecazlardır. Bunlar erkek egemen mesleklerde çalışan kadınların yaşadığı engelleri ifade eden kavramların aksine madalyonun diğer yüzü olan kadın egemen mesleklerde çalışan erkeklerin (azınlık durumundaki) yaşadığı durumları ifade etmekte kullanılmaktadır (Macarie ve Moldovan, 2012: 167). Kadın egemen mesleklerde çalışan erkeklerin erkek egemen mesleklerde çalışan kadınlarla benzer problemlerle yüzleştiğini öneren çalışmaların aksine, Williams'ın (1992) kadın egemen şirketlerde çalışan 100 erkek ile yaptığı çalışmada bu durum delillerle çürütülmüştür. Dolayısıyla cinsiyet farklıı̆̆ı nedeniyle erkeklerin kadın egemen mesleklerde daha kolay terfi ettiği ifade edilebilir. Cam asansör metaforu daha hızlı bir yükselişi ifade etmesine rağmen, cam yürüyen merdiven ve cam asansör kavramları birbirinin yerine kullanılabilir (oxfordindex.oup.com, 2015).

Cam uçurumun uzantıları olan cam asansör ya da cam yürüyen merdiven kavramları "şirketin yetkili sınıfı tarafından erkekleri zirveye taşıyan görünmeyen bir aracı" ifade etmektedir. Cam yürüyen merdiven ilkokul öğretmenliği, hemşirelik, kütüphanecilik ve sosyal yardım gibi kadın egemen mesleklerdeki erkeklerin, erkek egemen mesleklerdeki kadınlardan daha yükseğe, daha hızlı ve daha kolay nasıl yükseldiğini ya da nasıl daha fazla terfi fırsatı elde ettiğini betimler (Williams, 1992: 254; Macarie ve Moldovan, 2012: 157; Meharoof, 2010: 20; Madichie, 2013: 91-92; thefullwiki.org/Glass ceiling, 2015). Cam yürüyen merdiven metaforu, özellikle kadın egemen işlerde kurumsal hiyerarşi içerisinde erkekleri yukarı çıkaran yapılar ve uygulamaları vurgulamaktadır (Williams, 1992).

Başka bir deyişle, geleneksel olarak "kadın meslekleri" olarak bilinen işlerde ve kadın egemen işyerlerinde çalışan erkekler kendilerini daha yukarı ve daha "erkeksi" konumlara iten norm ve beklentilerin örtülü yönlerini tecrübe ederler. Bu sebeple bazılarını (sıklıkla kadınları) engelleyen cam tavan, başkalarına (sıklıkla erkeklere) bir cam yürüyen merdiven sunabilir. Ancak, cam merdiven eşcinsel veya siyahi erkekler gibi "kadın işlerini” yapan tüm erkeklere eşit şekilde açık değildir; cam yürüyen merdiven hem cinsiyetçi hem de ırk ayrımcılığı yapan bir kavramdır (Lamsa vd., 2012: 9). Erkekleri üst pozisyonlara kadınlara göre daha hızlı bir şekilde çıkaran bu uygulama kadınların işle ilgili 
çıktılarını etkileyecektir. Dolayısıyla cam asansör ve cam yürüyen merdivenin kadın çalışanların işle ilgili çıktılarını olumsuz etkileyeceği önerilmiştir.

Önerme 1: Cam asansör / cam yürüyen merdiven algısı şirketlerdeki kadın çalışanların işle ilgili çıktılarını (iş tatmini, örgüte bağılık, iş performansı) olumsuz yönde etkiler.

\subsection{Göstermecilik}

Göstermecilik (tokenism) ise, minimum ödün verme / terfi uygulamasıdır. Simge (token) kadın görüşü hâkimdir. Kadınları ve azınlık grup üyelerini kapsayacak şekilde göstermelik bir çaba veya jest yapma politikasını ifade etmektedir. Kanter'ın (1977) tokenism teorisine, "erkek egemen organizasyonlarda çalışan simge kadınların daha az gelir elde etmesinin veya yükselmelerinin engellemesinin bir açıklaması olarak" yaygın bir biçimde başvurulur. Örneğin, erkeklerin baskın olduğu mesleklerde kadınların göstermelik olarak şirket itibarını kurtarmak için işe alınması ve önemsiz komisyonlarda görev verilmesi bir tokenism uygulamasıdır ve bu durum kadınların terfi etmesini engellemektedir. Aksine kadın egemen işlerdeki (örneğin hemşirelik) simge erkeklerin bu azınlık statüsünden bir dezavantaja maruz kalmadığı hatta fayda elde ettiği söylenebilir ki bu durum cam asansör kavramını desteklemektedir (Budig, 2002: 259).

Kanter (1977), tokenizm koşullarını sosyolojik olarak farklı bir grubun örgüt üyeleri içerisindeki payının yüzde 15 ve daha azını oluşturduğu bir durum olarak tanımlar. Örgüt içerisindeki davranışları etkileyen üç faktörden bahsetmiştir: (1) Simgeler (tokenler, azınlıklar) kendi performansları üzerinde baskı yaratılacak daha fazla görünürlüğe sahiptirler. (2) Baskın grup (erkekler) ve azınlıklar (kadınlar) arasındaki farklılıkların abartılma eğilimi vardır. (3) Simgeler (kadınlar), basmakalıpsal cinsiyet rollerini asimile etmeye (benzetmeye) çalışılar. 1970'lerin sonlarında Rosabeth Moss Kanter tarafından yazılan kitapta "simge (token)" fikri şekillenmiştir. Kanter, erkek akranları arasında sayıca az olan ve sıklıkla "tek kadın" statüsünü taşıyan bu kadınların, simge olmasından bahsetmiştir. Erkek egemen bir yönetim grubunda bir kadın simge haline geldiğinde, oldukça görünebilir bir şekilde ve kolayca basmakalıplaştırılabilir bir halde tüm kadınların temsilcisi haline gelir. Örneğin, kadın lider ya bir “Demir Leydi" ya da kurnaz, mağdur veya her iki cinse de uyan bir uzman olarak temsil edilebilmektedir. Yönetim konumunda olan kadın kendi cinsiyetinin temsilcisi olarak görülürken, erkek "nötr" bir insandır. Göstermecilik/göstermelik ödün verme (tokenism) kuramı, kadınların yönetimle ilgili kariyerlere yani geleneksel olarak erkeklerin bulunduğu mesleklere girmesiyle karşılaştıkları zorlukları inceler ve yönetim alanında kadınların eşitliğine yönelik çoğu engelin daha fazla kadının yönetim pozisyonlarında işe alınmasıyla azaltılabileceğini önerir (Lamsa vd., 2012: 7). Kadınların bazı pozisyonlarda aktif rol alamamaları, inisiyatiflerinin kısıtlaması ve sadece göstermecilik bağlamında yapılan terfiler kadınların işle ilgili çıktılarını etkileyecektir. Dolayısıyla göstermeciliğin kadın çalışanların işle ilgili çıktılarını olumsuz etkileyeceği önerilmiştir.

Önerme 2: Göstermecilik algısı şirketlerdeki kadın çalışanların işle ilgili çıktılarını (iş tatmini, örgüte bağlıık, iş performansı) olumsuz yönde etkiler. 
Sebahattin YILDIZ

\section{3. Çifte Açmaz}

Çifte açmaz kavramı ise davranışsal normlara atıf yapar ve bir kadının ne yaparsa yapsın asla başarıı ve kazanan taraf olmayacağı bir durumu yaratma çabasını ifade eder (Bateson Jackson, Haley ve Weakland, 1956: 3). Çifte açmaz bir kişinin doğal ikileme karşı koyamadığı ve bu yüzden onu ne çözebildiği ne de vazgeçebildiği durumlarda olmaktadır (Puceitaite, 2012: 8-9). Psikoloji dilinde çatışma toplumsal (communal) ve bireysel (agentic) olma gibi iki ilişki ağı arasındadır. Kadınlar diğerlerine merhametli davranışta bulunma eğilimini ifade eden toplumsal özelliklerle ilişkilidirler. Kadınlar özellikle duygusal, yardımsever, arkadaşcıl, nazik ve sempatik olma eğilimindedirler. Aksine erkekler hükmetme ve iddia etme eğilimini ifade eden bireysel özelliklerle ilişkilidirler. Erkekler agresif, gayretli, hükmeden, kendine güvenen ve güçlü olma eğilimindedirler. Bunun bir sonucu olarak kadın liderler kendilerini bir çifte açmazla karşı karşıya bulacaklardır. Eğer kadınlar yüksek bir şekilde toplumsal olurlarsa, yeteri kadar bireysel olmamakla eleştirileceklerdir. Eğer kadınlar yüksek bir şekilde bireysel olurlarsa, toplumsalık eksikliği ile eleştirileceklerdir. Her iki şekilde de, kadınlar zorlu işler için doğru şeylere sahip olmadıkları izlenimi bırakabilirler. Bu çifte açmaz durumunda, insanların erkeklerden ziyade kadınların etki alanına daha fazla karşı koyucu olmaları oldukça şaşırtıcıdır. Örneğin şirket toplantılarında, insanlar erkeklerin aleni girişimlerine kadınlarınkinden daha olumlu tepki verirler. Bir şirketin kadın yöneticisinin deyimiyle "Insanlar sesli bir şekilde erkeklerin hatalarını savunma eğilimindedirler. Kadınlar aynı şeyi yaptıkları zaman yerilir ve küçük düşürülürler. Kadınlar hükmetme garibesi (control freaks) olarak yaftalanırlar. Erkekler aynı şeyi yaptıklarında ise heyecanlı (passionate) olarak isimlendirilirler (hbr.org, 2016).

Kadın bir yöneticinin ne yaparsa yapsın başarıı olamayacağı bir durumu yaratan bir davranışsal normu ifade eden çifte açmazın kökeni, Gregory Bateson tarafından 1950'lerin ortalarında güçlü ve güçsüz birey arasındaki veya sosyal ve kurumsal normlar ile hassas bir sını arasındaki kazanma neticesi olmayan paradoksal duruma işaret etmek amacıyla açıklanmıştır. Bateson ve diğerleri (1956)'ne göre, biri mağdur olmak üzere iki veya daha fazla insanın, birbiriyle çelişen emirler dolayısıyla mağdurun kaçamadığı ve bu yüzden çifte açmaz nedeniyle anksiyete ve stres yaşadığı belirtilmektedir. Jamiesson (1995)'a göre yönetim alanında kadınlar için tipik çift açmaz örnekleri şunlar olabilir: (Aktaran Lamsa vd., 2012: 7-8). Kadınların yönetici olarak ciddiye alınmaları için sert ve otoriter olması gerekir, fakat eş zamanlı olarak da geleneksel kadınsı (feminen) biçimde "normal kadınlar" gibi davranmaları beklenir. Konuşan kadın edepsiz görülürken, sessiz kadın da yok sayılır. Kadınsı olarak görülen kadınlar yetersiz görülürken, yeterli kadınlar da kadınsı görülmez. Erkekler yaşlandıkça bilge haline gelir ve güçlenirken, kadınlar yaşlandıkça kırışır ve lüzumsuz kalabalık ederler. Çifte açmazların üstesinden gelmek için atılacak önemli bir adım dilin kullanımına dikkati çekmektir. Dil bizim odağımızı ve algılarımızı değiştirebilir. Örneğin, yöneticilerden bahsederken "bravo beyler" demek yerine "herkese tebrikler" ya da iş adamları yerine iş insanları ifadeleri tercih edilebilir. Dilin cinsiyet hassasiyeti ile kullanılması, çoğu kadının yönetim pozisyonlarda karşılaştığı "aşağı tükürsen sakal, yukarı tükürsen bıyık" durumunu anlamaya ve onun üstesinden gelmeye yardımcı olabilir (Lamsa vd., 2012: 7-8). 
Çifte açmaz kavramı kadınların ilerlemelerini sınırlandıran bir engeldir ve kadınların iki arada bir derede kaldıkları durumu ifade eder. Bu durum davranış, konuşma biçimi ve kılık kıyafete kadar uzanır ve kadınları bıçak sırtında bırakır (Özkaplan, 2013: 9). Yani bir kız gibi görünüp, bir bayan gibi davranacak ve bir erkek gibi düşünüp bir patron gibi çalışmaları gerekecektir. Hem saygı duyulup hem de sevilmek erkeklere aittir, kadınlar ya saygı duyulup sevilmeyecek ya da sevilip saygı duyulmayacaktır, onların birisini tercih etmeleri gerekir. Ne yapsalar başarıları eleştirilecek kadınların işle ilgili çıktıları etkilenecektir. Dolayısıyla çifte açmazın kadın çalışanların işle ilgili çıktılarını olumsuz etkileyeceği önerilmiştir.

Önerme 3: Çifte açmaz algısı şirketlerdeki kadın çalışanların işle ilgili çıktılarını (iş tatmini, örgüte bağlıık, iş performansı) olumsuz yönde etkiler.

\subsection{Cam Labirent}

Cam labirent kavramını Eagly ve Carli (2007) önermiştir ve bu labirent metaforu (mecaz) bir kadının kariyer gelişiminde çok fazla engelle karşı karşıya kaldığını ve bunların doğruluğunu kabul ettiğini belirtir. Bu kavram bir anlamda kadınların yöneticilik yolundaki zorlu serüveni anlatmaktadır (Meharoof, 2010: 20; Nandy, Bhaskar ve Ghosh, 2014: 136; Klenke, 1997a: 57-58; Pucetaite, 2012: 8). Cam labirent, dolambaç olarak da ifade edilen bir çıkış yolu bulma ve amaca ulaşma, ya da organizasyonda güce doğru bir yol bulma olarak da düşünülebilir. Eagly ve Carli tarafından cam tavan kavramının yerine kullanılmıştır. Onlar, kadınların kariyerlerinde yüzleştikleri en iyi metaforun labirent terimi olduğuna inanmaktadırlar. Çünkü bu kavram çarpışmaya değer bir amaca doğru karmaşık bir seyahat fikrini taşımaktadır. Bu labirentten geçiş basit ve doğrudan değildir fakat birisinin gelişiminde sebat, farkındalık ve ilerideki hileli bulmacanın dikkatli bir analizini gerektirir (hbr.org, 2016). Birçok kadın, şirketin en üst merdivenin altında başarılı kadınları zirveye ulaşmaktan alıkoyan bir cam tavanın (görünmeyen engel) olup olmadığını sorgulamaktadır. Alice H. Eagly ve Linda L. Carli, Harvard Business Review'daki bir makalede böyle bir engelin olmadığını fakat kariyer yolu boyunca kadının karşılaştığı tüm engellerin (cam labirent) kadını uygun pozisyona ulaşmaktan alıkoyduğunu ifade etmektedirler (forbes.com, 2016).

Eagly ve Carli (2007), cam tavan metaforunu, sorunun kökenine inecek müdahaleleri dikkate almadığını söyleyerek eleştirmiştir. Klenke (1997a) ile hem fikir olarak yönetim ve liderlik amaçlarını güden kadınların karşılaştığı engeller için daha iyi bir metaforun labirent olacağını belirtmişlerdir. Labirent metaforu kadınların yönetici ve liderler olarak yolculuklarını engellemeyi amaçlar. Önce yönetimle ilgili kariyer labirentinde yol açan, fakat sonra yollarını bulmakta güçlük çeken kadın yöneticilerin imajını vurgular. Labirent metaforu fikri kurumların kadınların kariyer ilerlemelerinde karşılaştıkları engelleri anlamalarına ve ele almalarına yardım eder. Belirli tek bir engeli göstermekten ziyade, labirent yol boyunca ortaya çıkan mücadelelerin karmaşıklığı ve çeşitliliğini belirtir. Eagly ve Carli'ye göre (2007), labirentten geçmek kişinin kararlıı̆ını, içinde bulunduğu sürecin farkındalığını ve dikkatli düşünmesini gerektirir ve merkeze doğru birçok virajlı ve dönüşlü rotalar bulunmaktadır. Bu metafor engelleri kabul etmekte ama kadınların kariyer sürecindeki sorunların üstünden gelmesi 
Sebahattin YILDIZ

için olumlu bir yaklaşımı da içermektedir (Lamsa vd., 2012: 8). Kariyeri boyunca karşılaştığı tüm engellerin kadınları kariyer hedeflerinden alıkoyması onların işle ilgili çıktılarını etkileyecektir. Dolayısıyla cam labirentin kadın çalışanların işle ilgili çıktılarını olumsuz etkileyeceği önerilmiştir.

Önerme 4: Cam labirent algısı şirketlerdeki kadın çalışanların işle ilgili çıktılarını (iş tatmini, örgüte bağlıık, iş performansı) olumsuz yönde etkiler.

\subsection{Cam Duvar}

Cam duvar kadınların üst düzey yönetici olmaları yolundaki diğer bir görünmez bir engeldir (Klenke, 1997b: 5-6). Cam duvar kadın ve azınlıkların şirket içerisinde yatay olarak hareketinde yüzleştiği zorluğu ifade eder. İş ortamında genellikle şu bilinir ki bir kişinin yukarıya doğru yükselmesinde öncelikle işi öğrenmesi için yatay olarak bir departmandan diğerine hareket edebilmesi gerekir. Kadın ve azınlıkları yatay olarak hareketten alıkoyan bu görünmeyen engeller cam duvar olarak bilinmektedir (ehow.com, 2016). Görünmeyen bu ayrımcılıkta, kadınların erkek meslektaşları ile başarılarını karşılaştırma şansları olmamaktadır. Stratejik önemi olmayan insan kaynakları vb bölümlere yerleştirilen kadın kariyer hedefine ulaşamamaktadır. Kariyer eğer bir trene benzetilirse erkekler şehirler arası hatta, kadınlar ise banliyo hatta yer almaktadılar (dailymail.co.uk, 2016).

Cam duvar muhtemelen diğer kategorideki (erkek ve beyaz) personellerde bir problem olarak gözükmezken sadece bir kategorideki personelin yana doğru hareketini engellemektedir. Bu engel azınlıktaki kadınların her departmanda değil finans, ürün geliştirme vb stratejik olan ve üst yönetime giden kariyer yollarına geçişte uygulanmaktadır (answers.com, 2016). Cam duvar geleneksel olarak doğasında kadınsı olarak görülen belirli tür faaliyet alanlarında (yatay katmanlaşma) kadını tutan engellerdir (Sabharwal, 2013: 399). Kadınları üst kademe yöneticiliğe taşıyacak pozisyonlardan alıkoyan uygulamalar kadınların işle ilgili çıktılarını etkileyecektir. Dolayısıyla cam duvarın kadın çalışanların işle ilgili çıktılarını olumsuz etkileyeceği önerilmiştir.

Önerme 5: Cam duvar algısı şirketlerdeki kadın çalışanların işle ilgili çıktılarını (iş tatmini, örgüte bağlıık, iş performansı) olumsuz yönde etkiler.

\subsection{Cam Uçurum}

Cam uçurum, cinsiyet ayrımclığının cam tavandan sonraki ikinci formunu ifade etmektedir (Ryan ve Haslam, 2007: 550). İşletme yazınında Ryan ve Haslam (2005) tarafından kullanılan cam uçurum kavramı, kadınların, şirketin başarısızık riskinin yüksek olduğu ya da tehlikeli liderlik pozisyonlarına erkeklerden daha fazla getirilmesini ifade etmektedir (Ryan ve Haslam, 2005: 81). İş yerinde cinsiyet ayrımcılığının bir formu olan cam uçurum atamalarının altında yatan faktörler; işyerinde cinsiyetçilik, kadınların destekleyici ilişki ağları eksikliği, liderler ve kadınlarla ilgili basmakalıplar arasında (yönetici düşün erkek düşün) algılanan uyumsuzluk, kadınlar ve kriz yönetimiyle ilgili basmakalıplar arasında (kriz düşün kadın düşün) algılanan uyumdur (Ryan, Haslam ve Postmes, 2007: 185). 
İlk olarak Judge (2003) yönetim kurullarına kadınları atayan şirketlerin yönetim kurullarında sadece erkeklerin bırakıldığı şirketlere göre performansının kötüye gitme eğiliminde olduğunu öne sürmüştür. Buna eleştiri olarak Ryan ve Haslam (2005) kadınları yönetim pozisyonlarına atayan şirketlerin aslında atamadan önceki dönemde düşük performans düzeyinde olduklarını ortaya çıkarmıştır ve bu pozisyonlar için cam uçurum kavramını ilk kez kullanmıştır. Adams vd. (2009) ise, şirketlerin finansal performansının "atamadan önceki dönem dahil” iyi olduğu zamanlarda CEO pozisyonuna kadınların atandığından bir cam uçurum olmadığını belirtmiştir. Ryan ve Haslam (2009) ise, Adams vd. (2009) çalışması sonuçlarını eleştirerek cam uçurumu ölçmenin kolay olmadığını ve sadece finansal performans ile cam uçurumun belirlenemeyeceğini belirten derleme bir çalışma sunmuşlardır. Haslam vd. (2010) ise Adams vd (2009) çalışmasına eleştiri olarak kadınların yönetim kurullarında temsili ile subjektif piyasa tabanlı performans ölçümleri (Tobin's $Q$ ) arasında negatif ilişki bulunmuş ve cam uçurumun geçerli olduğunu teyit etmiştir. Fakat Haslam vd. (2010) aynı çalışmasında, kadınların yönetim kurullarında temsili ile objektif muhasebe tabanlı performans ölçümleri (ROA, ROE) arasında ilişki olmaması nedeniyle cam uçurumun desteklenmediğini belirtmiştir. Mulcahy ve Linehan (2014) ise, borsadaki şirketlerin tehlikeli durumu arttıkça kadınların şirketlerin yönetim kurullarında aşırı temsil olasılığının arttığına ulaşmıştır ve dolayısıyla cam uçurum desteklenmiştir.

Cam uçurum atamasının sadece ikincil verilerle değil çalışanlar veya öğrencilerin algılamaları yoluyla da ölçüldüğü gözlenmiştir. Haslam ve Ryan (2008: Çalışma 1)’a göre, işletme yönetimi mezunları şirket performansının yükselmesinden ziyade düşüş gösterdiği zaman liderlik pozisyonu için kadın adayı erkek adaydan daha atanabilir (liderlik yeteneği ve uygunluk bakımından) algılamışlardır. Haslam ve Ryan (2008: Çalışma 2)'a göre, yüksekokul öğrencileri büyük ölçekli bir müzik festivalindeki yönetim pozisyonuna, festivalin popülerliğinin düştüğü ve başarısızlık riskinin arttığı durumda erkek adaydan ziyade kadın adayı tercih etmişlerdir. Haslam ve Ryan (2008: Çalışma 3)'a göre, iş adamlarının/kadınlarının finans müdürü pozisyonu için şirket performansının azaldığı dönemde kadın adayı daha fazla uygun algılamışlardır. Ryan vd. (2010)’a göre, siyaset bilimi öğrencileri genel seçimlerde kazanması zorlu koltuk yarışı (büyük pay muhalefette) için kadın başkan adayını erkek adaydan daha fazla tercih etmiştir. Ryan vd. (2011: Çalışma 2)'ne göre, başarısız şirketlerde ideal yönetici tipinin kadınlar olacağı dolayısıyla kriz düşün kadın düşün ilişkisi kurulmuştur. Cook ve Glass (2013)'a göre, basketbol liginde başarısız veya kaybeden takımlara beyazlardan ziyade ırksal/etnik azınlıklar (siyahi koçların) atanmıştır. Ashby vd. (2007)'e göre, hukuk öğrencileri kolay davalardan ziyade riskli davalarda kadın avukatı tercih etmişlerdir. Ryan vd. (2011: Çalışma 3)'ne göre, düşük performans dönemlerinde kadınlar durumu iyileştireceği düşünülmediğinden, iyi yönetici olarak görülmediklerinden ve örgütsel başarısızlığın suçlusu olacaklarından desteklenmiştir. Kulich vd. (2014)'ne göre, seçimlerinde siyahi/azınlık adaylar beyaz adaylara göre daha az başarı göstermiştir fakat bu başarısızlık beyaz rakipleriyle karşılaştırıldığında daha büyük çoğunluktaki koltuğu sahip rakiplerine göre kazanılabilirliğin düşüklügü̈yle yani çoğunluk grupla karşılaştırıldığı zaman kazanmanın zor olduğu bir yarışla açıklanmıştır.

Cam uçurum kavramı, "kadının yetkinliğinden dolayı ya da şsirketi başarıya ulaştıracağı beklendiğinden değil, sadece kariyer hedeflerinden uzaklaştırmak, stres altında kalmalarına neden olmak 
Sebahattin YILDIZ

ve başarısızlığın sorumlusu ilan etmek için şirketlerin olumsuz finansal performans dönemlerinde kadınların üst kademelere getirildiği [hileli] pozisyonları" ifade etmektedir (Yıldız vd, 2016: 1132).

İsyerinde "kadınların özgür kılınması, eğitim programlarına katılması, tokenizm gibi göstermelik örgütsel politikaların kaldırıması, aktif mentorluk programları, grup tabanlı karar alma bilincinin oluşturularak homojenliğin önlenmesi ve pozitif ayrımcılık" gibi cam tavanı kırmaya yönelik stratejiler (Ryan ve Haslam, 2007) cam uçurumu anlamakta yararlı olabilir. Cam uçurumu açıklamakta kullanılan kategoriler; "cinsiyetçilik (cinsiyet engeli), grup içinde tercih edilme (erkek işi), kadınları feda etme ve sorumluluğu başkası üzerine atma (günah keçisi arama), fırsat eksikliği (kadınlar riskli pozisyonları kabul ederler), ilişki ağları ve destek eksikliği (materyal, entelektüel ve duygusal destek), cinsiyet basmakalıpları (riski dengeleme yeteneği, başarısızlıkla başa çıkabilme, riskli durumlarda daha yetenekli olma), eşitliği gösterme (cam tavan yoktur izlenimi için boş olan riskli pozisyona kadınları atamak), şirket faktörleri (farklı bir şeyler yapmak, son umut ve şirket imajını iyileştirmek için kadınları atamak), fenomenin inkar edilmesi (cam uçurum sorgulanır, pozisyon için en iyi aday atanmıştır denir)" dir (Ryan vd., 2007: 188-191). Cam uçurum ne evrenseldir ne de kaçınılmazdır (Ryan ve Haslam, 2009).

Liderlik pozisyonlarında erkeklerin rolü ya da cam uçurum çalışması sosyal psikoloji alanında oldukça tartışılan bazı kuramlarla açıklanabilir (Sabharwal, 2013: 399). Bu kuramlar "yönetici düşün erkek düşün (yöneticilerin işi erkeksidir ve erkekler için daha uygundur; duygusal denge, agresiflik, kendine güven, rekabetçilik, objektiflik gerektirir), sosyal rol (erkekler bireysel (agentic) yani agresif, kararlı, kendine güvenen, bağımsız ve baskın davranırlarken; kadınlar toplumsal yani kibar, nazik, şefkatli, empatik ve duygulu davranırlar), rol örtüşmesi (sosyal ve liderlik rollerinde kadınlara karşı önyargıları açıklar. Kadınların toplumda yerine getirmesi gereken sosyal roller ve liderlik rollerinin gerektirdikleri arasında çatışma olduğu zaman bir uyuşmazlık ortaya çıkar)" dir. Dünyanın her tarafında kadınlar ve erkeklerin cam uçuruma verdiği tepkiler açık bir şekilde farklıdır. Kadınlar cam uçurum varlı̆̆ını kabul etmekte ve adaletsizlik, tehlike, cinsiyetçilik, fırsat eşitsizliği ve engel algılamaktayken, erkekler cam uçurumun geçerliliğini sorgulamakta ve küçümseyerek önemsiz görmektedir, ayrıca bunu ılımlıca açıklamakta, zor liderlik görevleri için uygun olmaya, stratejik karar verme ihtiyacına ve cinsiyetle ilişkisiz şirket faktörlerine bağlamaktadırlar (Ryan vd., 2007).

Kadınların uçurumdan düşme olasılığı, "politika oluşturma kararlarını etkilediklerinde, güçlendirme algıladıklarında, örgütsel adaleti tecrübe edindiklerinde ve iş-yaşam dengesinden tatmin durumunda" daha azalmaktadır (Sabharwal, 2013: 400). Yıldız, Sakal ve Alhas (2016: 509) Türkiye'de yaptıkları çalışmalarında öğrenci örnekleminde cam uçurumun geçerli olamayabileceğini belirterek, bu durumu Türkiye'nin dişillik kültürü ile açıklamışlardır.

Kadınların olumsuz dönemlerde üst kademeye getirilip uçuruma sürüklenmesi kadın çalışanların işle ilgili çıktılarını etkileyecektir. Dolayısıyla cam uçurumun kadın çalışanların işle ilgili çıktılarını olumsuz etkileyeceği önerilmiştir. 
Önerme 6: Cam uçurum algısı şirketlerdeki kadın çalışanların işle ilgili çıktılarını (iş tatmini, örgüte bağlıık, iş performansı) olumsuz yönde etkiler.

Yukardaki tüm önermeleri içeren teorik model Blau'nun (1964) Sosyal Mübadele Teorisi çerçevesinde Şekil 1'de gösterilmiştir.

Şekil 1. Teorik Bir Model Önerisi

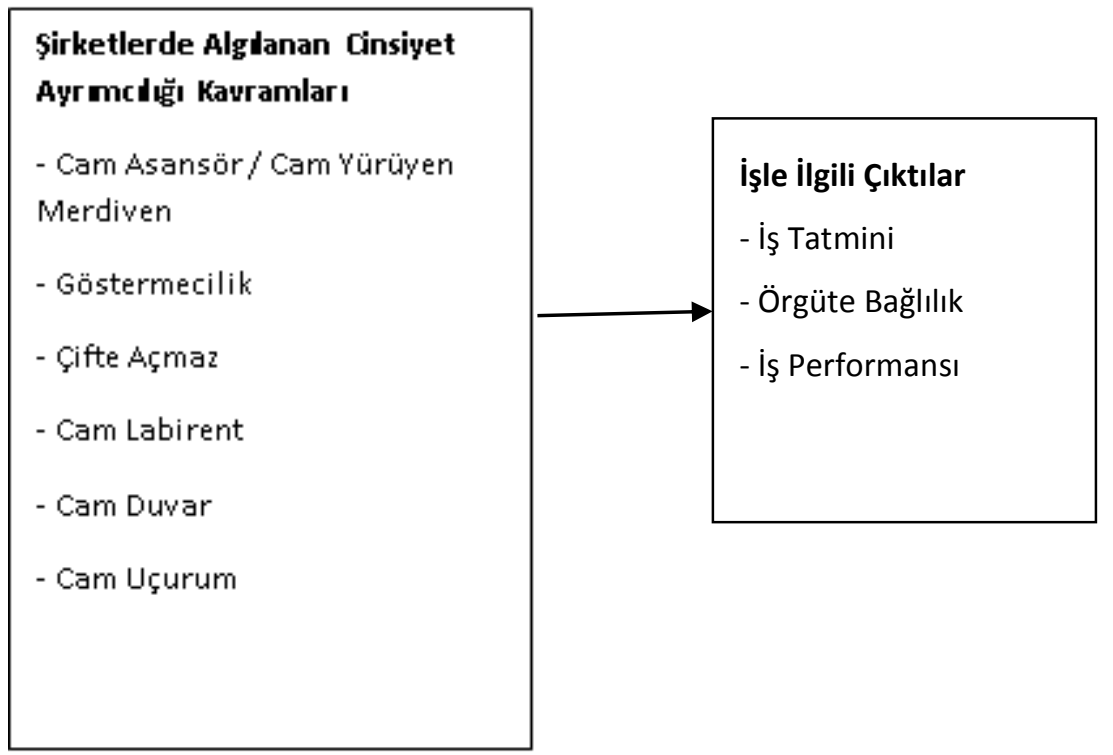

\section{Sonuç ve Öneriler}

Bu çalışmada, şirketlerde cam tavan dışında cinsiyet ayrımcılığıyla ilgili cam uçurum, cam asansör, cam yürüyen merdiven, cam labirent, cam duvar, çifte açmaz, göstermecilik gibi kavramların da olduğu ortaya çıkarılmış ve bu kavramların temelleri toplumsal cinsiyet ve feminist kuramlar bağlamında açıklanarak Türkçe yazına tanıtılmıştır. Ayrıca bu kavramları tanıtma amacının yanında, Blau'nun (1964) sosyal mübadele teorisine dayanarak kadınların bu cinsiyet ayrımcılığı kavramlarıyla ilgili algılarının işle ilgili tutum ve çıktılara olan (iş tatmini, örgüte bağlılık ve iş performansı) olumsuz etkisi üzerine bir model de geliştirilmiştir.

Aslında liberal feministlerin belirttiği gibi yasal olarak kadınlar ile erkekler eşit haklara sahiptir. Bu durum Anayasa'nın 10. Maddesinde, İş Kanunu'nun 5. Maddesinde (tbmm.gov.tr, 2016) ve ILO sözleşmelerinde (ilo.org, 2016) belirtilmiştir. ILO sözleşmelerine göre kadın sadece maden ocakları ve yeraltı işlerinde (kablo döşemesi, kanalizasyon ve tünel inşaatı gibi) çalıştııılamaz (Cengiz vd., 2012: 17). Kadın yasal olarak bu işler dışında her türlü işte ve yöneticilik pozisyonunda çalışabilir. Dolayısıyla kadınların üst kademe yönetici olmalarında herhangi bir yasal engel yoktur. Fakat ikinci dalga feministlerin de ifade ettiği gibi "cinsiyet ayrımcılığı ve eşitsizlik" ataerkil toplum yapısının kadın çalışanlara koymuş olduğu yukarıdaki kavramlarda bahsedilen kariyer engellerinden dolayıdır. 
Sebahattin YILDIZ

Beşeri (insan) ve sosyal sermaye kuramları da toplumsal cinsiyet eşitsizliğinde dikkate alınmalıdır. Beşeri sermaye kuramı daha nitelikli, eğitimli bireylerin daha başarılı olacağını ileri sürmektedir. Sosyal sermaye kuramı ise başarıyı bireylerin daha iyi bağlantılara yani ağlara sahip olmasıyla ifade etmektedir. Kadın ve erkekler benzer beşeri sermaye özellikleriyle donatılıyor olsa bile kadınların sosyal sermaye birikimlerini engelleyen, yani kadınların toplumda ilişki ağlarında yer almalarını engelleyici unsurlar ortadan kaldıılmadığında kadınların güç hiyerarşisinde dikey olarak yükselmeleri ve sosyal sermayeye sahip olmaları zor olacaktır (Başak, 2013: 232). Dolayısıyla beşeri sermayesini sosyal sermayeye dönüştüremeyen kadın üst kademeye yükselememektedir.

Alt/orta düzey yönetici kadınların çoğunluğunun halkla ilişkiler, pazarlama gibi üretim dışı ya da stratejik olmayan alanlarda olduğu saptanmıştır (mesleki yatay katmanlaşma) (Özkaplan, 2013: 45). Bunun nedeni bilimsel, teknolojik ve mühendislik alanlarında çalışan kadınların doğum nedeniyle işten belirli bir süre ayrılıp geri döndüklerinde teknolojinin ve değişimin çok gerisinde kalarak üst kademeye zaten ulaşmalarının zor olması ve bu nedenle öğretmenlik, hemşirelik gibi meslekleri tercih etmeleridir.

Kamusal alanın erkeğe, özel alanın ise kadına; ev dışı işlerin erkeğe, ev içi işlerin kadına; birincil piyasaların erkeğe ikincil piyasaların kadına layık görülmesi, arz ve talep temelli piyasalarda kadınların ve işverenlerin tercihlerinin farklı olması ve doğal farklılıklar yerine kültürel oluşturulan farklılıklara göre ayrımcılı̆ıın yapılması şirketlerde bahsedilen bu kavramları ortaya çıkarmakta ve eleştirilmektedir.

Ilerleyen çalışmalarda toplumsal cinsiyetten kaynaklanan bu cinsiyet ayrımcılığı kavramlarının ve bunların işle ilgili çıktılar üzerindeki etkisi için geliştirilen model önerisinin, Türkiye'de geçerli olup olmadığının nicel bir araştırma modeliyle ölçümlenmesi uygun olacaktır. Farklı kültürel bağlamlarda birincil veya ikincil veriler yoluyla araştırmalar yapmaya gerek vardır. Ayrıca bu kavramlara ilave olarak Türkçe yazında yer almayan kurtarıcı etkisi (savivor effect), yapışkan zemin (sticky floor) ve pasif üye sendromu (dead wood syndrome) gibi kavramlar da incelenebilir veya yenileri üretilebilir.

\section{Kaynaklar}

Adams, S.M., Gupta, A. ve Leeth, J.D. (2009). "Are Female Executives Over-Represented in Precarious Leadership Positions?", British Journal of Management, 20, 1-12.

Aktaş, G. (2013) “Feminist Söylemler Bağlamında Kadın Kimliği: Erkek Egemen Bir Toplumda Kadın Olmak", Edebiyat Fakültesi Dergisi, 30(1), 53-72.

Alican, A. (2007), Kamu Memur Sendikalarında Çalışan Yönetici Kadınlar, Yayımlanmamış Yüksek Lisans Tezi (Isparta: Süleyman Demirel Üniversitesi).

Ashby, J., Ryan, M.K. ve Haslam, S.A. (2007). “Legal Work and The Glass Cliff:Evidence that Women Are Preferentially Selected to Lead Problematic Cases",William \& Mary Journal Women and The Law", 13(3), 775-793. 
Bateson, G., Jackson, D.D., Haley, J. ve Weakland, J. (1956). “Toward a Theory of Schizophrenia”, Behavioral Science, 1(4), 251-254

Başak, S. (2013). “Toplumsal Cinsiyet”, Editörler: İ. Çapçıoğlu ve H. Beşirli, Sosyolojiye Giriş, Grafiker Yayınları, Ankara.

Blau, P.M. (1964). Exchange and Power in Social Life, Transaction Publishers, London.

Budig, M.J. (2002). “Male Advantage and The Gender Composition of Jobs: Who Rides the Glass Escalavator", Social Problems, 49(2), 258-272.

Cengiz, M., Temir, A. Ve Birsen, E. (2012). 60 Soruda Kadın İş̧ilere Özel Çalışma Koşulları El Kitabı, Uluslar arası Çalışma Örgütü, Ankara.

Cook, A. ve Glass, C. (2013). "Glass Cliff and Organizational Saviors: Barriers to Minority Leadership in Work Organizations?”, Society for The Study of Social Problems, 60(2), 168-187.

Çakır, S. (2010). “Feminizm: Ataerkil İktidarın Eleştirisi”, Derleyen: H. Birsen Örs, Modern Siyasal İdeolojiler, İstanbul Bilgi Üniversitesi Yayınları, İstanbul.

Demir, Ö. (2011). "Feminizm ve İktisat", Editör: Veysel Bozkurt ve Fadime Güneş, Ekonomi Sosyolojisi, Anadolu Üniversitesi Yayınları, Eskişehir, 94-115.

Eagly, A.H. ve Carli, L.L. (2007). Through the Labyrinth: The Truth About How Women Become Leaders, MA: Harvard Business School Press, s. 1-5, [Erişim: 10.11.2015, https://www.google.com.tr].

Ensher, E.A., Grant-Vallone, E.J. ve Donaldson, S.I. (2001). "Effects of Perceived Discrimination on Job Satisfaction, Organizational Commitment, Organizational Citizenship Behavior, and Grievancez", Human Resource Development Quarterly, 12 (1): 53-72.

Erbay, E. ve Tuncay, T. (2006). "Sosyal Hizmet Bakışıyla Kadın İstihdamı”, Toplum ve Sosyal Hizmet Dergisi, 17(2), 25-40.

Ersoy Çak, Ş. (2010). "Toplumsal Cinsiyet ve Feminizm Teorileri Bağlamında Türkiye'deki Reklam Filmleri ve Popüler Müzik Videoları”, DEÜ GSF Dergisi, 4, 101-110.

Giddens, A. (2012). “Cinsellik ve Toplumsal Cinsiyet (12. bölüm)”, Çeviren: İsmail Yılmaz, Sosyoloji, Kırmızı Yayınları, İstanbul.

Güldü, Ö. Ve Ersoy Kart, M. (2009). “Toplumsal Cinsiyet Rolleri ve Siyasal tutumlar: Sosyal Psikolojik Bir Değerlendirme”, Ankara Üniversitesi SBF Dergisi, 64 (3), 97-116.

Haslam, S.A. ve Ryan, M.K. (2008). "The Road to Glass Cliff :Differences in the Perceived Suitability of Men and Women for Leadership Positions in Succeedings and Failing Organizations", Leadership Quarterly, 1-56. 
Sebahattin YILDIZ

Haslam, S.A, Ryan, M.K., Kulich, C., Trojanowski, G. ve Atkins, C. (2010). "Investing with Prejudice: The Relationship Between Women's Presence on Company Boards and Objective and Subjective Measures of Company Performance, British Journal of Management, 21 (2), 484497.

http://www.answers.com, Erişim Tarihi: 27.02.2016.

http://www.dailymail.co.uk, Erişim Tarihi: 27.02.2016.

http://www.ehow.com, Erişim Tarihi: 27.02.2016.

http://www.forbes.com, Erişim Tarihi: 27.02.2016.

http://www.hbr.org, Erişim Tarihi: 27.02.2016.

http://www.ilo.org/ankara/conventions-ratified-by-turkey/WCMS 377248/lang--tr/index.htm,

Erişim Tarihi: 23.03.2016.

http://oxfordindex.oup.com, Erişim Tarihi: 21.10.2015.

https://www.tbmm.gov.tr/anayasa/anayasa82.htm, Erişim Tarihi: 15.05.2016

https://www.tbmm.gov.tr/kanunlar/k4857.html, Erişim Tarihi: 15.05.2016

http://www.thefullwiki.org/Glass ceiling, Erişim Tarihi: 21.10.2015.

Judge, E. (2003). "Women on Board: Help or Hindrance?", The Times, (www.thetimes.co.uk, Erişim Tarihi: 09.05.2016).

Kanter, R. M. (1977). "Some Effects of Proportions on Group Life: Skewed sex rations and responses to token women", American Journal of Sociology, 82, 965-990.

Klenke, K. (1997a). "Women in the Leadership and Information Labyrinth Looking for the Thread of Ariadne", A Leadership Journal :Women in Leadership -Sharing the Vision, 1(2), 57-70.

Klenke, K. (1997b). Women's Leadership in Context,Women's in the Leadership Contextual Dynamics and Boundaries, Emerald Group Publishing Limited, UK.

Koçak Turhanoğlu, A. (2012). "Sosyoloji, Bilim ve Yöntem", Editör: Aşkın Koçak Turhanoğlu, Sosyoloji-1, Açıköğretim Yayınları, Eskişehir.

Kulich, C., Ryan, M.K. ve Haslam, S.A. (2014)."The Political Glass Cliff:Understanding How Seat Selection Contributes to The Under Performans of Ethnic Minority Candidates", Politics Research Quartely, 67(1), 84-95.

Lamsa, A.M., Jyrkinen, M. Ve Heikkien, S. (2012). "Women in Managerial Careers", Editor. Pucetaite, R. Cases in Organizational Ethics, Vilnuis University Press, Lithunia, 4-16. 
Macarie, F.C. ve Moldovan, O. (2012). "Gender Discrimination in Management Theoretical and Emprical Perpectives", Transylvanian Review of Administrative Sciences, (35), 153-172.

Madichie, N.O. (2013). "Sex in the Kitchen:Changing Gender Roles in a Female - Dominated Occupation", International Journal of Entrepreneurship and Small Business, 18(1), 90-102.

Meharoof, A.R. (2010). Glass Ceiling: Myth or Reality?, Masters Degree in Social Works, Mangalore.

Mulcay, M. ve Linehan, C. (2014). "Females and Precarious Board Positions: Further Evidence of the Glass Cliff", British Journal of Management, 25 (3): 425-438.

Nandy, S., Bhaskar, A. ve Ghosh, S. (2014). “Corporate Glass Ceiling: An Impact on Indian Women Employees", International Journal of Management and International Business Studies, 4(2), 135-140.

Onay, M. (2009). “Algılanan Cinsiyet Ayrımcılığının Sonuçları ve Konuyla ilgili Ampirik bir Araştırma”, Ege Akademik Bakış, 9(4), 1101-1125.

Özkaplan, N. (2013). "Kadın Akademisyenler: Cam Tavanlar Hala Çok Kalın”, Kadın Araştırmaları Dergisi, 12, 1-23.

Parlaktuna, i. (2010). “Türkiye'de Cinsiyete Dayalı Mesleki Ayırım Analizi', Ege Akademik Bakış Dergisi, 10(4), 1217-1230.

Peng, K.Z., Hang-Tue, N., Junqi, S. ve Chi-Sum, W. (2009). “Gender Differences in the Work Commitment of Chinese Workers: A Investigation of Two Alternative Explanations",Journal of World Business, 44, 323-335.

Puceitaite, R. (2012). Cases in Organizational Ethics, Kaunas Faculty of Humanities, Vilnius University, Lithuania.

Ryan, M.K. ve Haslam, S.A. (2005). "The Glass Cliff: Evidence that Women are Over-Represented in Precarious Leadership", British Journal of Management, (16), 81-90.

Ryan, M.K. ve Haslam, S.A. (2007). "The Glass Cliff: Exploring The Dynamics Surrounding The Appointment of Women to Precarious Leadership Positions, Academy of Management Review, 32(2), 549-572.

Ryan, M.K., Haslam, S.A. ve Postmes, T. (2007). "Reactions to Glass Cliff: Gender Differences in The Explanations for The Precariousness of Women's Leadership Positions", Journal of Organizational Change Management, 20(2), 182-197.

Ryan, M.K. Ve Haslam, S.A. (2009). "Glass Cliffs Are Not So Easily Scaled: On The Precariousness of Female CEO's Positions", British Journal of Management, (20), 13-16.

Ryan, M.K., Haslam, S.A., Hersby, M.T. ve Bongiorno, R. (2011). "Think Crisis -Think Female:The Glass Cliff and Contextual Variation in The Manager -Think Male Stereotype", Journal of Applied Pyschology, 96(3): 470-484. 
Sabharwal, M. (2013). "From Glass Ceiling to Glass Cliff: Woman in Senior Executive Service", Journal of Public Administration Research and Theory, June 14, 1-29.

Sanchez, J.I. ve Brock, P. (1996). “Outcomes of Perceived Disrimination Among Hispanic Employees: Is Diversity Management A Luxury or Necessity", Academy of Management Journal, 39 (3), 704 719.

Shaffer, M.A., Joplin, J.R., Bell, M.P., Lau, T ve Oğuz, C. (2000). “Gender Discrimination and JobRelated Outcomes: A Cross-Cultural Comparasion of Working Women in the United States and China", Journal of Vocational Behavior, 57, 395-427.

Williams, C.L. (1992). "The Glass Escalator: Hidden Advantages for Men in the "Female"Professions", Social Problems, 39(3), 253-257.

Yıldız, S., Sakal, Ö. ve Alhas, F. (2016). "Cam Tavandan Cam Uçurum’a: Kriz Düşün Kadın Düşün”, 24. Ulusal Yönetim ve Organizasyon Kongresi, 29-31 Mayıs, İstanbul, 509-519.

Yıldız, S., Alhas, F., Sakal, Ö. ve Yıldız, H. (2016). "Cam Uçurum: Kadın Yöneticiler Cam Tavanı Ne Zaman Aşar?”, Ankara Üniversitesi SBF Dergisi, 71 (4), 1119-1146.

Yoğun Erçen, A.E. (2008). Kadınların Cam Tavanı Aşma Stratejileri: Büyük Ölçekli Türk Işsletmelerinde Bir Inceleme, Çukurova Üniversitesi SBE Doktora Tezi, Adana. 